\title{
A burial textile from the first century CE in Jerusalem compared to roman textiles in the land of Israel and the Turin Shroud
}

\author{
Orit Shamir ${ }^{\mathrm{a}}$ \\ Curator of Organic Materials, Israel Antiquities Authority
}

\begin{abstract}
Although the grave in the Ben Hinnom Valley (Akeldama) in Jerusalem was visited by robbers, there was a single, sealed and untouched loculus. Upon opening this grave a black mass of material and bones were found. The mass itself appeared to be made up of fabric and human hair. The bones in this loculus had not been gathered for a secondary burial, as was the custom for Jewish burials at the beginning of the first millennium CE.

The textile fragments belong to a shroud. The deceased was buried with the shroud because there was no secondary burial. The tomb was probably sealed because of leprosy and there was no bone-collecting after a year. The shroud is made of wool. The Z-spin of the wool suggests production outside of Israel as Z-spun threads form only a small proportion of textiles in Israel and its neighbouring countries in the Roman period. The wool textile from the Ben Hinnom Valley could, therefore, have been imported from Greece or Italy in which Z-spinning was the norm. I will compare this discovery to: a. Textile evidence from burials found in the Land Israel; $b$. The Mishnaic and Talmudic sources; c. Textiles from the Roman period discovered in the Land of Israel; $d$. The Turin shroud.
\end{abstract}

\section{Introduction - The akeldama area}

The confluence of the Kidron and Ben Hinnom Valleys, south of the Old City of Jerusalem, contains one of Jerusalem's richest concentrations of rock-hewn tombs. This area, located on the periphery of the village of Silwan, was one of the main burial Necropolis during the Second Temple period, 538 BCE until 70 CE [1].

The caves and chambers represent the Jewish burial customs during the Second Temple period, and they help us to determine the use of the textile fragments which were discovered in this area.

The burial caves were carefully carved in the hard limestone formations. Each of the tombs is comprised of a main chamber with loculi with the occasional entrance chamber. Thick rock walls usually separate the chambers with only small openings connecting them. The burial customs included a primary burial within loculi and a secondary bone collection in ossuaries. It seems that this custom had been introduced late in the Second Temple period, probably around the mid-first century BC.

\footnotetext{
a e-mail: orit@israntique.org.il
}

This is an Open Access article distributed under the terms of the Creative Commons Attribution License 4.0, which permits unrestricted use, distribution, and reproduction in any medium, provided the original work is properly cited. 


\section{SHS Web of Conferences}

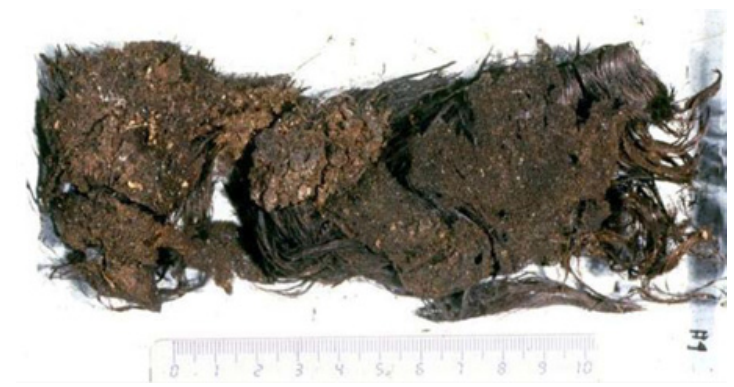

Figure 1. Jerusalem, Akeldama, human hair covered with wool textile. (IAA. No. 2003-9028/1). (C) Israel Antiquities Authority; photo: Clara Amit.

The unique decorative features in the caves, as well as the high quality of workmanship, indicate that these were the burial caves of some of the more affluent Jewish families of the city.

During November 1998 a burial complex in the Ben Hinnom Valley was examined after it had been breached and plundered by antiquities thieves [2]. The tomb comprised a simple entrance cut into a quarried scarp leading to rectangular rock-hewn chambers on two levels, Steps lead from the entrance into a square burial chamber, No. A, with nine loculi, kokhim in Hebrew. A doorway in the northern wall of the upper burial chamber, east of the main entrance, leads into the lower chamber, No. B. Six kokhim were hewn in the walls.

Twenty-eight of the stone ossuaries were found decorated with rosettes and geometric patterns, a few bearing inscriptions in Jewish and Greek script ("Mary"; "Shimon ben [sonof] Shulai"; "Salome"; "Phineas"). Human bones were scattered all over. Though no finds were recovered at this tomb such as coins and pottery or glass vessels, the plan of the complex and the secondary burial suggest a first century CE date.

\section{The burial}

Although the grave at Ben Hinnom Valley in Jerusalem had been illegally entered and looted, a single, closed loculus was found by the archaeologists. Upon opening this grave, a nondescript black mass of material was found along with bones. The mass itself appeared to be made from fabric and human hair (Fig. 1). A radiocarbon date of the shroud textile determined by the AMS radiocarbon laboratory in Texas (by D. Donahue) confirmed its early date: 95 BCE -53 CE [3].

This loculus was sealed and the bones had not been gathered for secondary burial as was the custom for Jewish burials at the beginning of the first millennium CE. In addition to being sealed, a crack above the loculus was probably responsible for the relative dryness of the site. This allowed water to be funneled off and was most likely a major determinant in preserving the site.

\section{The deceased}

The deceased was found to be male and has an mtDNA type that didn't match any of the four other individuals in the tomb. He suffered from leprosy and tuberculosis. Leprosy, on its own, does not kill, but it does cause immuno-suppression that allows opportunistic organisms, of which tuberculosis is a prime example, to kill the individual. Leprosy and the fear and revulsion it created seems to provide an explanation for the sealing and isolation of the loculus [4]. 


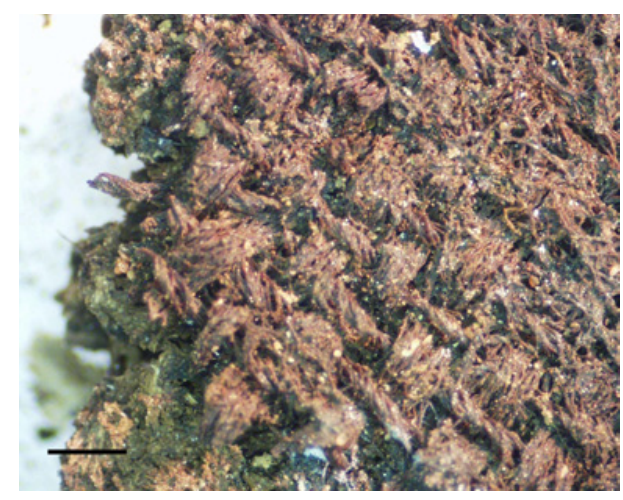

Figure 2. Jerusalem, Akeldama, wool, Z-spun, $\times 16$.

\section{The hair}

His hair was brown in color and appeared very clean and may have been washed in close proximity to death. No insects, head lice, or lice cases were observed. There were a few cuts on the distal ends of the hair shaft, which may indicate that the hair was cut shortly before death [5].

\section{The textile fragments}

The discovery of textiles in the Jerusalem area is rare due to high levels of humidity that do not usually allow for the preservation of organic material. Insects probably caused the few holes (less than $0.5 \mathrm{~cm} \times$ $0.5 \mathrm{~cm}$ ). The textiles are carbonized and were also damaged by the relative humidity of Jerusalem and by body fluids. Because they were arranged in layers (when the body was wrapped) and stuck together, it is impossible to separate them without causing damage.

The loculus extended for $1.6 \mathrm{~m}$. Some parts of the body [6] were covered with a number of textile layers. The head of the deceased was also covered with remains of a $16 \times 16-\mathrm{cm}^{2}$ textile that was found adhered to the hair in one layer and apparently surrounded it.

The warp of the textile is Z-spun medium tight (Fig. 2). The weft is almost unspun (I-spun) and thicker than the warp. The textile is made of wool in plain-weave technique. The number of wool threads per $\mathrm{cm}$ is 19 in the warp and 16 in the weft, with some remains of the closing cord, indicating the edge of the textile. Microscopic examination of the wool exhibited no birefringence in polarized light, indicating that its organic material had decomposed.

A closing cord is very common on wool textiles of the Roman period [7] and also appears on linen textiles. It can be either S-twisted or Z-twisted. Closing cords were found at "En Rahel, Mo'a [8], Masada, Murabba' at, the Cave of Letters, Quseir al-Qadim [9], Nubia [10], Dura-Europos and Palmyra.

The textiles do not bear any darning or sewing, nor any signs of wear and tear or cutting. There is not any decoration. The textile wrapped the body and surrounds also the hair.

Wool textiles from the Roman period in Israel are usually S-spun. Z-spun textiles comprise only a small proportion of Roman-period textiles recovered in Israel and neighbouring countries, while in Greece and Italy, for example, the Z-spin was the norm [11]. Therefore the wool textile from Akeldama could have been imported. This would indicate that the individual came from a wealthy family. Importing a special and "fine" burial cloth would entail time and expense and would not be done for the common man. 

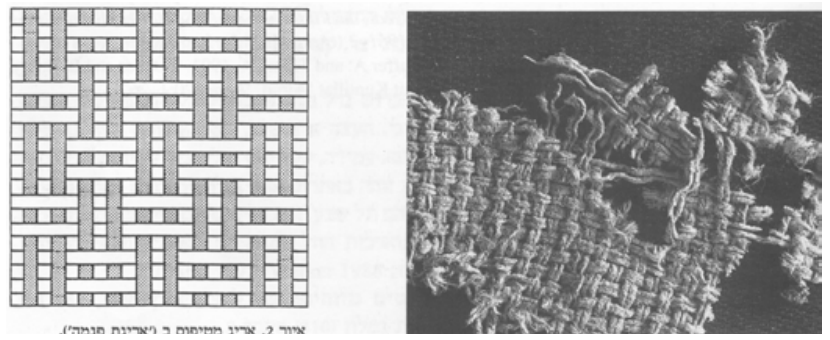

Figure 3. 'En Gedi, Extended tabby (basket weave) (IAA. No. 1983-123, 1983-149). Sheffer, A. 1994. Textiles from Tomb 2 at 'En Gedi, 'Atiqot 24:67, Pl. 2. OIsrael Antiquities Authority; photo: Clara Amit.

Several ossuaries (first century CE) in the tombs of Akeldama were inscribed with Greek names [12]. The glass vessels also show connections with Greece [13]. The finds illustrate the Jewish burial practices of Jerusalem during the first century CE.

\section{Textiles evidence from burials in the roman period Israel}

The use of wool textile in primary use for burials and shrouds is less common than linen in the Land of Israel and was usually used for shrouds in secondary use. Linen shrouds have been discovered at burials sites in the Land of Israel. Linen shrouds dating from the Roman period have been found also at 'En Gedi, Gesher Haziv [14], and Jericho - imprints of textiles were found on bones and skulls [15]; the material used was identified as linen because of an equal number of threads in the warp and the weft. Shrouds were also found at Nahal David and Ze'elim, but the fiber material was not specified in Ref. [16] and we could not examine them because they did not arrive to the Israel National collections.

The best preserved shrouds are from Roman-period 'En Gedi (2nd-1st centuries BCE, Second Temple period). They were found in eight Jewish tombs on the southern bank of Nahal "Arugot and in one tomb on the northern bank of Nahal David [17].

Seventy textile fragments of an undyed, cream-colored linen were preserved, the largest measuring $16 \times 12 \mathrm{~cm}^{2}$. Two varieties were observed, both of which used S-spun linen threads: Type A is a plain weave with $12 \times 10$ threads/cm; Type B, somewhat coarser, is an extended tabby (basket weave) with $8 \times 2$ by $6 \times 2$ threads/cm (Fig. 3) [18].

The textiles from 'En Gedi are assumed to have been shroud remnants. In Tomb 1, Coffin 4, textile fragments were found along the limbs and around the skull, and a knotted piece lay above the right shoulder of the deceased. The Mishnah mentions "the knot in the undershirt at the shoulder" [19]. A similar knot was found in Tomb 6, Coffin 2 (Fig. 4). The source of linen could be local Galilean, Beth She' an (Scythopolis) or the Jordan Valley including Jericho and not from Egypt [20].

It is interesting to compare these finds to the shrouds from the Nabataean burials at 'En Tamar dated to the Roman period, 2-3th centuries CE. The Nabateans controlled the Spice routes joining Petra and Gaza northwards to Syria and westwards to the Mediterranean. The shrouds are made of linen, but a small group of them is decorated with narrow wool red bands [21] (Fig. 5).

Wearing garments of mixed wool and linen - which is called in the Hebrew sources sha'atnez - is forbidden by the Jewish law [22] but it can be used to make shrouds for the deceased [23]. But none of the Jewish shrouds found in the above-mentioned archaeological sites and none of the shrouds made from reused textiles (see below) are made of sha'atnez.

Although thousands of textiles in the Land of Israel have been examined, no one piece of sha'atnez has been recovered from any Roman Jewish site [24]. This is in contrast with the Roman sites in neighboring areas, as for example in Syria at sites such as Dura Europos and Palmyra, and in Coptic 


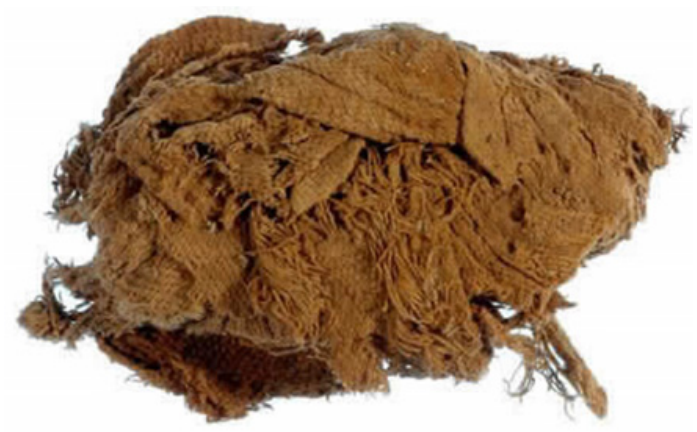

Figure 4. 'En Gedi, linen shroud with a knot lay above the right shoulder of the deceased. OIsrael Antiquities Authority; photo: Clara Amit.

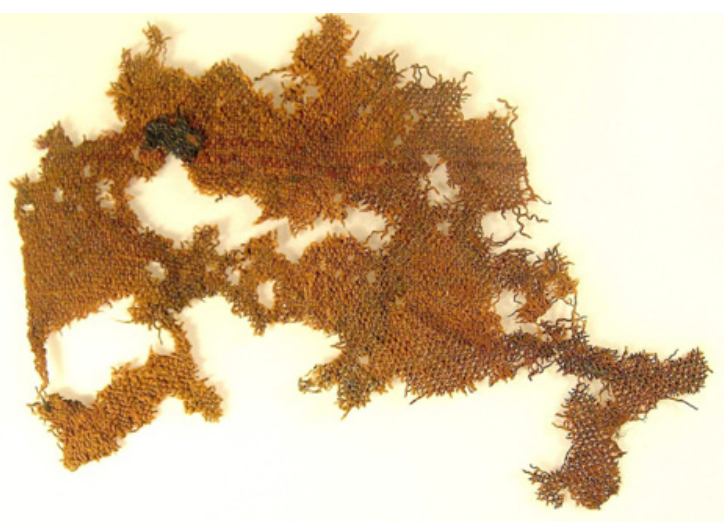

Figure 5. 'En Tamar, linen shroud decorated with wool bands (IAA. No. 2003-9038). CIsrael Antiquities Authority; photo: Clara Amit.

Egypt, which have yielded a great deal of textiles made of mixed linen and wool. Yet a few pre-Roman sites in the Land of Israel have yielded sha'atnez textiles: Kuntillat 'Ajrud (Hurbat Teman) in Sinai dated to the first half of the 8th century BCE - the Iron Age II and Wadi ed-Dâliyeh (located $14 \mathrm{~km}$ northwest of Jericho) contained artefacts belonged to Samaritan refugees and is dated to the Hellenistic Period. In both cases it was explained as belonging to the High Priest and priests respectively which, according to the Hebrew Bible, was required to wear sha'atnez while serving in the Temple [25]. The almost complete absence of mixed wool and linen (sha'atnez) textiles at non-Jewish sites, such as the Nabatean ones, can be explained by the fact that the textiles in Israel during the Roman Period were produced by Jews and purchased by the non-Jewish population. There is a striking likeness between the Nabatean and Jewish textiles (1-2th centuries CE), including shaded bands and the number of threads per $\mathrm{cm}$ [26]. Parenthetically, the absence of sha'atnez in the Turin shroud is not an indication that it was originally weaved for some other purposes, such as a sheet connected with the ritual immersions of the High Priest on Yom Kippurt, Jesus' tallit (mantle) or tablecloth of the Last Supper as was suggested by some scholars [27] (but there are other indications that it was reused, see below).

The linen shrouds found in the Land of Israel and mentioned above are undyed cream or biege but not white which caused by bleaching. This is in contrast with to the Talmudic sources which mention 
white shrouds [28]. Bleaching was a long process intended to whiten linen textiles, which are naturally of a grey-brown color. The textiles were soaked in cleaning and whitening chemicals and were then exposed to the sun for weeks, during which time they became white. Bleach textiles were usually made for clothing such as at Masada, the Cave of Letters, Qumran but also for scroll wrappers (e.g. Qumran) [29]. The Turin shroud is yellowish and color fibers are visible next to uncolored fibers [30].

\section{Shrouds made from reused textiles}

Shrouds were sometimes made from reused textiles. Most of the shrouds in the Cave of Letters were made from tunics and mantles, usually made of wool, that had been ripped apart for this purpose. Linen sacks were also in secondary use as shrouds [31]. This kind of burials can be explained by the harsh siege conditions of the Roman army on the Jewish population under the Roman siege. At Khirbet Qazone, a Nabatean cemetery in Jordan dating to the first century CE, some of the deceased were found with reused textiles still wrapped around them [32]. At Dura-Europos a covering or a curtain was in secondary use as the wrapping for the deceased person [33]. At Palmyra the corpse were wrapped first in several layers of simple cloth in secondary use, usually linen; finally, a sort of outer decoration made of sumptuous garments cut into strips for sepulchral purposes was arranged in a decorative manner on the wrapped body. This custom explains why most of the textiles found at Palmyra were preserved in bands of different sizes [34]. In Krokodilopolis and Herakleopolis Magna, some of the sheets used as burial wrappings bear extensive darning, evidence that they were previously used in life [35]. In Nubia, shrouds were often made of several pieces of cloth sewn together to produce a sufficient length and width to envelop the body, indicating that the cloths were not especially woven for funerary purposes [36].

Textiles were too costly to throw away. When a garment had passed the state where patching was no longer possible, it was cut into pieces and either remade into another garment or used for patches [37].

Despite the fact that the Land of Israel was considered an important textile center, there was a chronic shortage of garments in general, and of linen ones in particular. Such linen garments were quite rare and certainly very expensive [38].

\section{The mishnaic and talmudic sources}

Preparation for a Jewish burial consisted mainly of washing the corpse and wrapping it in shrouds [39]. Shrouds were specially-prepared or freshly laundered garments for the purpose of wrapping the corpse. The Hebrew word for these burial shrouds, takrikim, connotes wrapping and binding more than dressing as is also indicated by Tractate Semahot: "Man may wrap and bind men but not women, but women may wrap and bind both men and women" [40]. In preparation for burial, spices and incense are often placed upon the shroud [41].

To honor the dead the family has to bury him within the day when the dead occurred: "One who delays the burial of his deceased thereupon performs a transgression. (On the other hand) if he delayed (the burial) for the deceased's honour, (in order) to bring him a sarcophagus or shrouds, that is not considered a transgression" [42].

During the late Second Temple period it became common to spend great sums on expensive shrouds [43]. The rich grew-very extravagant in this respect, securing fanciful and costly garments, and establishing a custom which became a burden upon mourners of the middle and poorer classes, who could ill endure the expense and yet desired to show the highest respect for their dead. Thus Rabban Gamaliel inaugurated the custom of using a simple linen shroud for rich and poor alike. It is uncertain whether the reference is to Rabban Gamaliel the Elder, who lived before $70 \mathrm{CE}$, or (more probably) to his successor Rabban Gamaliel II, of the Jabneh period (second half 1th-second half 2th centuries CE) [44]. 
Afterwards, the people followed his example and were also buried in linen garments. Said Rav Papa, "Nowadays, everybody uses even "tsadra" (rough cloth) which costs one zuz (a minimal sum)" [45].

Rabbi Judah the Patriarch [46], who died in the early third century CE, directed that he not be buried with many shrouds. The Jerusalem Talmud explains that the Rabbi was of the opinion that "a person will not come as he left"; thus, he need not worry that his burial garments are appropriate for resurrection. A simple sheet was sufficient and, if he merits a place in the World to Come, he will be dressed appropriately at the proper time.

Other commentators, in contrast, believed that one's state at resurrection would be the same as at the time of burial. Rabbi Yohanan is reported to have requested that he be buried in garments that were neither black nor white - so that, whether he find himself standing among the righteous or the wicked in the World to Come, he would not be ashamed. Rabbi Yoshaya on the other hand, commanded that he be buried in proper white garments, as he was not ashamed of his righteous deeds. Finally, Rabbi Jeremia is reported to have directed that he be buried with proper garments, sandals and a walking staff.

A burial in garments was also possible: To which kind of corpse does (the law of) "rot" apply? It applies to that which is buried naked, in a sarcophagus of stone or on a floor or a marble tablet. But one who is buried in his garment or in a coffin of wood or on the ground, here (the law of) "rot" does not apply [47]. One who weaves a "garment for the deceased" (for a specific individual, after his death), Abbayeh says: "Prohibited (its use for anything else)" and Rava says: "Permitted" [48]. The Talmud also refers to a fine-wool robe covering a corpse [49].

\section{The Turin Shroud}

Jesus's body was wrapped in clean linen cloth [50]. The author of the Gospel according to John agrees that spices were used and these were wrapped in the linen cloths, "according to the burial custom of the Jews" [51]. Additional information on the use of shrouds can be found in John: "The dead man came out, his hands and feet bound with bandages, and his face wrapped with a cloth" [52].

The Akeldama discovery immediately suggested to the media some comparisons with the Shroud of Turin. The detailed characterization of the weave has allowed them to be compared to the Turin shroud, providing additional proof for them that the latter is not authentic [53].

The Turin shroud is made of linen Z-spun in a 3/1 herringbone twill pattern. All the linen textiles from the Land of Israel until the medieval period are S-spun, plain weave tabby. A few wool textiles from the Roman period are Z-spun in both warp and weft (37 out of 826 wool textiles) [54].

The Turin shroud has 38.6 threads per $\mathrm{cm}$ at the warp and 25.7 threads per $\mathrm{cm}$ at the weft which is very high compared to linen textiles manufactured at the Land of Israel which usually have 10-15 threads per $\mathrm{cm}$ at the warp and 15-20 threads per $\mathrm{cm}$ at the weft [55].

The textiles from the Roman period in the Land of Israel were made on a warp-weighted loom or two-beam upright loom. The warp-weighted loom went out of use in the region at the end of the $1 \mathrm{st}$ century CE, when the vertical, two-beam upright loom became popular [56]. Despite the fact that looms capable of weaving twill existed in this period and even before, twill has not been found in Israel prior to the Roman period. The weave was found in small quantities among wool textiles (32 out of 1635 textiles from Roman period sites) including the Cave of Letters (one item), the Judean Desert caves survey (one item), Masada (13 items, Fig. 6), Mo'a (9 items), Murabba'at (6 items) and Sha'ar Ramon (2 items) [57].

The twill variations are: twill $2 / 2$, twill $1 / 2$ and diamond twill; one herringbone twill textile was found at Murabba'at [58], but it seems to be a modern-day textile. Most of the twills are Z-spun. Twill textiles can be manufactured with three heddles loom which were not in use in Israel. It means that the twills were imported. Herringbone twill textiles are known from Europe and Egypt [59]. 


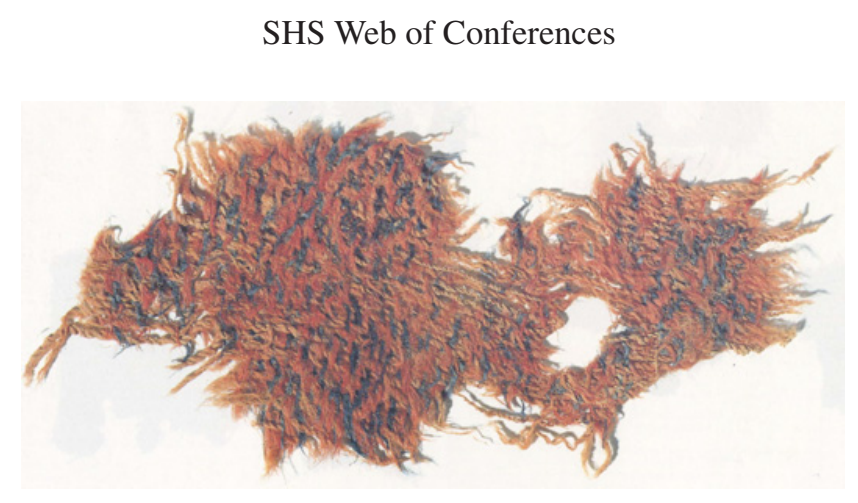

Figure 6. Masada, Z-spun, wool, complex diamond twill (IAA. No. 1993-9011). Sheffer, A. and Granger-Taylor, H. 1994. Textiles from Masada - A Preliminary Selection, Aviram Y, Foerster G. and Netzer E. (eds.) Masada IV. Jerusalem, Pl. 7b. Courtesy of the the Israel Exploration Society.

Run and fell seams which were used to stitch textiles together were used, according to Flury-Lumberg [60], only during the Roman period, even though they were found also in textiles from the Medieval period as at Kasr al-Yahud from the ninth century CE [61].

\section{Discussion and conclusions}

Although the paper cannot cover all the aspects of this demanding subject-matter, some highlights, supplemented by further details and concluding remarks, are summarized below for the benefit of the reader.

Material.- The Jerusalem shrouds illustrate the Jewish burial practices of Jerusalem during the Roman period, insofar as they substantially agree, excluding the material - wool -, with the description of the Mishnaic and Talmudic sources. Wool was the most common textiles material in the Roman Period in Israel (900 of 1635, Table 1), where linen was also very popular (662 of 1635, Table 1).

Further materials that were used are mixed wool and linen, goat hair and camel hair (Table 1). Instead, linen was prefered for shrouds in the Land of Israel according to these sources and to the archaeological evidence. As is known, the Turin Shroud is also made of linen.

Spinning.- The Akeldama shroud is Z-spun. But most of the textiles in the Land of Israel from the Roman period are S-spun (715 of 826, Table 2). A few are Z-spun in both warp and weft, usually made of wool (37 of 826, Table 2) [62].

Weaving and Density.- Plain weave or tabby was the most common weave for garments and other used including the the shrouds. Twill is a tighter form and thus more able to stand greater wear than tabby [63] but, as stated above, it was found in small quantities in the Land of Israel and was imported. The number of threads per $\mathrm{cm}$ is lower than that of the Turin shroud which is $3 / 1$ herringbone twill pattern with high density of threads.

Edges.- Akeldama shroud has only closing cord which was preserved. Typical edges during the Roman period are starting borders, closing borders, different types of selvedges and fringes [64]. The Turin shroud is cut from a bigger bolt. Three edges are cut and the fourth one is a selvedge. The side strip lining (that is stitched to the main part of the shroud) and the main cloth are part of the same bolt of fabric [65].

Origin.- The Akeldama shroud was imported from a place, notably Greece or Italy [66], where the common tradition of Z-spun was maintained. The Turin Shroud was probably not manufactured in the 
Table 1. Textile Materials from the Roman Period in Israel (in alphabetical order).

\begin{tabular}{|c|c|c|c|c|c|c|}
\hline Site & No. of textiles & Linen & Wool & Goat hair & Camel hair & Mixed \\
\hline 'En Gedi (burial) & 70 & 70 & & & & \\
\hline $\begin{array}{l}\text { 'En Gedi Cave } 138 \\
\text { (H. Eshel, unpublished) }\end{array}$ & 1 & & 1 & & & \\
\hline 'En Rahel & 98 & 7 & 66 & 25 & & \\
\hline 'En Tamar (burial) & 133 & & 130 & & & 3 \\
\hline Akeldama (burial) & 2 & 1 & 1 & & & \\
\hline Avior cave & 13 & 9 & 3 & 1 & & \\
\hline Cave of Letters Yadin Excavations & 92 & 35 & 57 & & & \\
\hline Cave of Letters 2000-1 Excavations & 276 & 20 & 256 & & & \\
\hline Cave of the Treasure & 25 & 24 & 1 & & & \\
\hline Gesher Haziv (burial) & 1 & 1 & & & & \\
\hline Horbat Qazra & 1 & & 1 & & & \\
\hline Jebel Abu Saraj Cliff, Cave IV/12 & 9 & 8 & 1 & & & \\
\hline Judean Desert Caves survey & 37 & 27 & 10 & & & \\
\hline Masada* & 129 & 12 & 105 & 12 & & \\
\hline Mo’a & 333 & 66 & 248 & 14 & & 5 \\
\hline Murabba'at & 86 & 17 & 68 & 1 & & \\
\hline Nahal Hever Caves & 8 & 3 & 5 & & & \\
\hline Pool Cave** & 15 & 11 & 4 & & & \\
\hline Qumran & 71 & 71 & & & & \\
\hline Qumran (unpublished) & 150 & 103 & 42 & 5 & & \\
\hline Sha'ar Ramon & 10 & 1 & 8 & & & 1 \\
\hline $\begin{array}{l}\text { Wâdi ed-Dâliyeh } \\
\text { (including Hellenistic period) }\end{array}$ & 55 & 36 & 12 & & 3 & 4 \\
\hline Wâdi el-Makkukh, Cave III-8 & 21 & 10 & 11 & & & \\
\hline Total & 1635 & 662 & 900 & 58 & 3 & 13 \\
\hline
\end{tabular}

*Thousands of textiles, presumably including wool ones to a large extent, from Masada are still not accommodated in the current literature.

**Excavated recently by $\mathrm{H}$. Cohen. The textiles were not catalogued because they were not cleaned yet.

Table 2. Wool Spin Direction from the Roman Period in Israel*.

\begin{tabular}{|l|l|l|l|l|l|}
\hline Site & S-spun & Z-spun & S/Z & $\mathbf{Z} / \mathbf{S}$ & $\begin{array}{l}\text { Other } \\
\text { combinations }\end{array}$ \\
\hline Akeldama (burial) & & 1 & & & \\
\hline Avior cave & 3 & & & & \\
\hline Cave of Letters Yadin Excavations & 46 & 2 & 8 & & 1 \\
\hline Cave of Letters 2000-1 Excavations & 234 & 1 & & & \\
\hline Cave of the Treasure & 1 & & & & \\
\hline 'En Gedi Cave 138 (H. Eshel, unpublished) & 1 & & & & \\
\hline 'En Rahel & 63 & 2 & & & 1 \\
\hline Jebel Abu Saraj Cliff, Cave IV/12 & 1 & & & & \\
\hline Judean Desert Caves Survey & 10 & & & & \\
\hline Wâdi el Makkuk, Cave III/8 & 10 & 2 & & & \\
\hline Masada & 74 & 13 & 11 & 3 & $16^{* *}$ \\
\hline Mo'a & 191 & 8 & 17 & 3 & 9 \\
\hline Murabba'at & 62 & 2 & & & 4 \\
\hline Nahal Hever Caves & 4 & 1 & & & \\
\hline Horbat Qazra & \multicolumn{1}{|l}{} & 1 & & \\
\hline Sha'ar Ramon & 4 & 4 & & & \\
\hline Wâdi ed-Dâliyeh (including Hellenistic period) & 11 & 1 & & & \\
\hline Total & $\mathbf{7 1 5}$ & $\mathbf{3 7}$ & $\mathbf{3 7}$ & $\mathbf{6}$ & $\mathbf{3 1}$ \\
\hline
\end{tabular}

*Not including spin direction of the bands.

**In seven items, S-spun and Z-spun yarns were used together in either warp or weft. 
Land of Israel neither in the Roman nor in the Medevial period. It may not have been imported in none of these periods because not one textile with the above weaving technique was found in the Land of Israel.

\section{Acknowledgements and information}

The author wish to thank Dr. Naama Sukenik, Amit Reem and the anonymous Referee for his/her useful suggestions aimed to improve the paper.

The Israel Antiquities Authority's (IAA) Nash Family Center for Ancient Textiles and Organic Materials includes a wealth of textiles, basketry, cordage, wood and leather artifacts, as well as fruits and seeds, dating from $8000 \mathrm{BCE}$ until $1800 \mathrm{CE}$ and deriving from excavations conducted throughout the country. A selection of objects from the collection can be viewed on the IAA's National Treasures Online website (www.antiquities.org.il/t/Default_en.aspx). The center and the collections are scheduled to move from their current location to the National Campus for the Archaeology of Israel, the IAA's archaeological research, conservation and illumination complex currently under construction on Museum Hill in Jerusalem and scheduled to open in April 2016. Some of the textiles which are presented in this paper will be stored there instead of within the currently used storeroom.

\section{References}

[1] Avni and Greenhut 1996

[2] The cave was documented on behalf of the Israel Antiquities Authority by Dr. Boaz Zissu, Dr. Simon Gibson and Prof. Jacob Tavor. Zissu, Gibson and Tavor 2000

[3] Matheson et al. 2009

[4] Matheson et al. 2009

[5] A. Gorski, pers. comm

[6] Matheson et al. 2009

[7] Sheffer and Granger-Taylor 1994, 181

[8] Shamir 1999, 94; Shamir 2005a

[9] Eastwood 1982, 286

[10] Bergman 1975

[11] Sheffer and Granger-Taylor 1994, 236-237

[12] Avni and Greenhut 1996, 18

[13] Winter 1996, 96

[14] Hadas, G. P. 1994; Shimoni and Shamir 1994

[15] Hachlili and Killebrew 1999, 169

[16] Aharoni 1961, 19; Avigad 1962, 182-183

[17] Hadas 1994

[18] Shamir 2006a; Sheffer 1994: 9*, 66-68

[19] Mishnah Miqvaot 10:4

[20] Midrash Rabbah, Genesis 19:1; Babylonian Talmud, Mo'ed Qatan 18b; Safrai 1994, 155-157; Shamir 1996, 142

[21] Shamir 2006b; Shamir 2014:298. This is in contra to hundreds textiles found at Nabataean sites and made of wool, linen, goat hair and camel hair but none of them is mixed wool and linen. Shamir 1999; 2003; 2004

[22] This is mentioned twice in the Hebrew Bible: It is written in Leviticus 19:19, where it is stated that "you shall not put on cloth from a mixture of two kinds of material". The prohibition of "the mixture of diverse kinds" material is mentioned additional contexts such as interbreeding different species of animals together, working different species of animals under the same yoke, and planting different species of seeds together in a single field. Sha' atnez garments are mentioned but the specific materials are not listed. In Deuteronomy 22:11, however, it is added that "You shall not wear cloth combining wool and linen" 
[23] Mishnah Kilayim 9:4; Babylonian Talmud Tranctate nidda 61b; Babylonian Talmud Tranctate Pesachim 40b; Grossi 2012:3

[24] But there are few examples of linen sewing threads on wool textiles: Cave of Letters and Masada which can be explained by the harsh siege conditions of the Roman army. Shamir 2015:298

[25] Crowfoot 1974, 60, 63; Shamir 2015:298; Sheffer \& Tidhar 2012

[26] Shamir 2015:302

[27] See a list of suggestions at Grossi 2012:3 including Rigato 2003:206-207 and Jackson 2000: $56-71$

[28] Grossi 2012:19

[29] Shamir and Sukenik 2011:220

[30] Lazzaro Murra 2015

[31] Yadin 1963, 204-205, 218, 237

[32] Granger-Taylor 2000; 2006; Politis 1998, 2006; Shanks 1999

[33] Pfister and Bellinger 1945, 34, No.116

[34] Pfister 1934, 14; Schmidt-Colinet 1995; Taha 1982, 118

[35] Linscheid 2001; Linscheid and Fluck 1995

[36] Bergman 1975:9

[37] Mannering 2000:15

[38] Babylonian Talmud, Pesachim 109a; Safrai 1994:201

[39] Mishnah Kilaim 9:4; Maasey Sheni 5:12; Tosefta Nedarim 2:7; Grossi 2012:9; Hachlili 2005; Safrai 1976, 776

[40] Mishnah Semahoth 8:7; Grossi 2012:17; Safrai 1976, 777

[41] Grossi 2012:9; Hachlili 2005:385, 482, 484

[42] Mishna Tractate Sanhedrin 6:5; Ben Yehuda; Grossi 2012:8

[43] Safrai 1976, 777

[44] Babylonian Talmud, Mo'ed Qatan 27b; Safrai 1976, 777; Rubin 1977, 202-206; Hadas 1994, 56; Kraemer 2000, 20

[45] Babylonian Talmud 8b; Ben Yehuda; Grossi 2012:10, 19

[46] Talmud Yerushalmi, Kilaim 9:3, 32a; Ketubot 12:3, 34d; Bereishit Rabbah 96

[47] Tosefta Tractate Tents 2, 3. Ben Yehuda

[48] Babylonian Talmud Tractate Sanhedrin 41-422; Ben Yehuda

[49] Babylonian Talmud Tractate Yebamoth 66b. Grossi 2012:10

[50] Mark 15:46

[51] John 19:39

[52] John 11:44

[53] Grossi 2012:21-22, but unfortunately didn't cite the excact information about the technical details of the textile from Shamir $2007 \mathrm{c}$

[54] Shamir O. 2007b:210

[55] Shamir O. 2007b:210

[56] Shamir 1994:277; 1996:148; Shamir 2007a; Sheffer and Granger-Taylor 1994: 231

[57] Shamir 2007b

[58] Crowfoot and Crowfoot 1961:52, 55

[59] Europe (Bender-Jørgensen 1993); Egypt: Abu Sha'ar (Bender-Jørgensen and VogelsangEastwood 1991), Maximianon, El-Zarqa (Mannering 1994), Quseir al-Qadim (Handley 2000)

[60] Flury-Lemberg 2001

[61] Shamir 2005b

[62] Shamir 2007d:207-217; 2013

[63] Vogelsang-Eastwood 1988:596 
[64] Shamir 2007d:231-234

[65] Grossi 2012:4-5

[66] Sheffer and Granger-Taylor 1994, 236-237

\section{Additional bibliography}

The vast majority of the author's papers are collected in: https://antiquities.academia. edu/OritShamir. Aharoni, Y. 1961b. The Expedition to the Judean Desert, Expedition B, Israel Exploration Journal 11:11-25

Avigad, N. 1962. The Expedition to the Judean Desert, Expedition A-Nahal David, Israel Exploration Journal 12:169-183

Avni, G. and Greenhut, Z. (eds.) 1996. The Akeldama Tombs. Three Burial Caves in Kidron Valley. Jerusalem

Bar-Adon, P. 1971. The Cave of the Treasure - The Finds from the Cave. Jerusalem

Bender-Jørgensen L. 1993. North European Textiles until AD 1000. Denmark

Ben Yehuda N. Shrouds for the Deceased - in Talmudic Literature. https://biu.academia.edu/NahumBen Yehuda

Bergman, I. 1975. Late Nubian Textiles (The Scandinavian Joint Expedition to Sudanese Nubia, Vol. 8), Lund

Crowfoot, G.M. and Crowfoot, E. 1961. The Textile and Basketry. In: P. Benoit et al. Discoveries in the Judaean Desert: Les Grottes De Murabba'at, vol. II, Oxford, Pp. 51-63

Crowfoot, E. 1974 Textiles. In P.W Lapp \& N.L. Lapp (eds.). Discoveries in the Wâdi ed-Dâliyeh, AASOR 41, 60-77

Cumont, F. 1926. Fouilles de Doura-Europos (1922-1923). Paris

Eastwood, G. 1982, Preliminary Report on the Textiles. In: D. S. Whitcomb and J. H. Johnson (eds.). Quseir Al-Qadim 1978 Preliminary Report. Princeton. Pp. 285-326

Flury-Lemberg, M., Spuren einer wechselvollenGeschichte auf dem Grabtuch von Turin, Das Münster 54, 2001, 17-29, Ill

Granger-Taylor, H. 2000, The Textiles from Khirbet Qazone (Jordan), Archéologie des Textiles des origins au Ve siècle Actes du colloque de Lattes, octobre 1999. Montagnac. Pp. 149-162

Granger-Taylor H. 2006. Textiles from Khirbet Qazone and the Cave of Letters. In: S. Schrenk (ed). Textiles in Situ: Their Find Spots in Egypt and Neighbouring Countries in the First Millennium CE. Riggisberger Berichte 13:113-134. Abegg-Stiftung, Riggisberg

Grossi A. 2012. Jewish Shrouds and Funerary Customs: a Comparison with the Shroud of Turin. https://independent.academia.edu/AdaGrossi

Hadas, G. P. 1994. Nine Tombs of the Second Temple Period at 'En Gedi, 'Atiqot 24, Jerusalem

Hachlili R. 2005. Jewish Funerary Customs Practices and Rites in the Second Temple Period. LeidenBoston-Köln

Hachlili R. and Killebrew, A. 1999. Jericho - The Jewish Cemetery of the Second Temple Period (Israel Antiquities Authority Reports 7), Jerusalem

Kraemer, D. 2000, The Meaning of Death in Rabbinic Judaism. London and New York

Lazzaro (Di) P., Murra D. 2015. Shroud like coloration of linen, conservation measures and perception of patterns onto the Shroud of Turin. A survey of experimental studies at the ENEA Research Center of Frascati.This book

Mannering U. 2000. The Roman Tradition of Weaving and Sewing: A Guide to Function? Archaeological Textiles Newsletter 20:10-16

Matheson C.D. et al. 2009. Molecular Exploration of the First-Century Tomb of the Shroud in Akeldama, Jerusalem. PLoS ONE 4(12): e8319. doi:10.1371/journal.pone.0008319 
Mazar, B. Dothan, T. and Dunayevsky, I. 1966. En Gedi - The First and Second Seasons of Excavations 1961-2. 'Atiqot 5. Jerusalem

Pfister, R. and Bellinger, L. 1945, Excavations at Dura Europos,. The Textiles, vol. IV,2, New Haven Politis K.D. 1998. Rescue Excavations in the Nabatean Cemetry at Khirbat Qazone 1996-1997. ADAJ 42:611-614

Politis K.D. 2006. The Discovery and Excavation of the Khirbet Qazone Cemetery and Its Significance Relative to Qumran. In: Galor K. (ed.) Qumran the Site of of the Dead Sea Scrolls. Leiden

Rubin, N. 1977, A Sociological Analysis of Jewish Mourning Patterns in the Mishnaic and Talmudic Periods. Ph.D. Dissertation. Bar Ilan University, Ramat Gan (Hebrew)

Safrai, Z. 1976, Home and Family> In: Z. Safrai and M. Stern (eds.) The Jewish People in the First Century, vol. II, Pp. 728-792, Assen

Safrai, Z. 1994. The Economy of Roman Palestine. London

Schmidt-Colinet, A. 1995, "The Textiles from Palmyra", ARAM 7:47-51

Shanks, H. 1999, Who lies Here? Jordan Tombs Match Those at Qumran, Biblical Archaeology Review 25:49-53

Shamir O. 1994. Loomweights from Masada. Masada IV. Eds. Y. Aviram, G. Foerster and E. Netzer. Jerusalem. Pp. 265-282

Shamir, O. 1996. Loomweights and Whorls. In: D.T. Ariel (ed.) Excavations at The City of David 1978-85, Directed by Y. Shiloh, Vol. IV (QEDEM 35). Pp. 135-170

Shamir, O. 1999, Textiles, Basketry, and Cordage from 'En Rahel, 'Atiqot 38:91-124.Shamir O. 2003, Textiles, Basketry and Cordage from Nabatean Sites along the Spice Route between Petra and Gaza. In: R. Rosental-Heginbottom (ed.). The Nabatean in the Negev. Haifa. Pp. 35-38

Shamir O. 2004. Coloured Textiles found along the Spice Route joining Petra and Gaza - Examples from the First Century CE to Eighth Century CE. In: L. Cleland and K. Stears (eds.). Colour in the Ancient Mediterranean World. BAR International Series 1267:49-52

Shamir O. 2005a. Textiles, Basketry, Cordage and Whorls from Mo'a. 'Atiqot 50:99-152

Shamir O. 2005b. Tunics from Kasr al-Yahud. In: L. Cleland, M. Harlow and L. Llewellyn-Jones (eds). The Clothed Body in the Ancient World. Oxbow books. Pp. 162-168

Shamir O. 2006a. Shrouds and Other Textiles From Ein Gedi. In: Y. Hirschfeld. Ein gedi "A Large Village of Jews". Haifa. Pp. 57*-59*

Shamir O. 2006b. Textiles, Basketry and Cordage and Fruits from 'En Tamar: Preliminary Report. In: P. Bienkowski and K. Galor. Crossing the Rift Valley. Oxbow Books. Levant Supplementary Series 3. Pp. 191-194

Shamir O. 2007a. Loom Weights from En-Gedi. In: E. Stern. En-Gedi Excavations I, Final Report (1991-1965). Jerusalem. Pp. 381-390

Shamir O. 2007b. PhD in Archaeology, titled "Textiles in the Land of Israel from the Roman Period till the Early Islamic Period in the Light of the Archaeological Finds", supervised by: Prof. G. Foerster and Dr. J. Peter-Wild, Institute of Archaeology-The Hebrew University in Jerusalem and Department of Art, History and Archaeology-University of Manchester

Shamir O. 2007c. Textiles from the $1^{\text {st }}$ Century CE in Jerusalem - a Preliminary Report. Ancient Textiles Production, Craft and Society. Oxford. Pp. 77-80

Shamir O. 2007d "Textiles in the Land of Israel from the Roman Period till the Early Islamic Period in the Light of the Archaeological Finds", PhD dissertation, supervised by: Prof. G. Foerster and Dr. J. Peter-Wild, Institute of Archaeology-The Hebrew University in Jerusalem and Department of Art, History and Archaeology-University of Manchester

Shamir O. 2013. Dress: Hellenistic and Roman Period. In: D. Master (ed.). Oxford Encyclopedia of the Bible and Archaeology. 2-Volume Set. Oxford. Pp. 328-336

Shamir O. 2015. Two Special Traditions in Jewish Garments and the Rarity of Mixed Wool and Linen Threads at the Same Textile in the Land of Israel. In: M. Harlow, C. Michel \& M.-L. Nosch (eds.), 


\section{SHS Web of Conferences}

Prehistoric, Ancient Near Eastern and Aegean Textiles and Dress: an interdisciplinary anthology. Ancient Textiles Series 18. Oxbow Books, Oxford. Pp. 303-314

Shamir O. and Sukenik N. 2011. Qumran Textiles and the Garments of Qumran's Inhabitants. Dead Sea Discoveries 18:206-225. Brill publications

Sheffer, A. 1994. Textiles from Tomb 2 at 'En Gedi, 'Atiqot 24:66-68 (Hebrew; English Summary, p. $9 *)$

Sheffer, A. and Granger-Taylor, H. 1994. Textiles from Masada - A Preliminary Selection, Aviram Y, Foerster G. and Netzer E. (eds.) Masada IV. Jerusalem, Pp. 153-256

Sheffer, A. \& Tidhar, A. 2012 Textiles and Basketry at Kuntillat 'Ajrud. In Z. Meshel et al. (eds.) Kuntillet 'Ajrud. An Iron Age II Religious Site on the Judeah-Sinai Border, 289-312(after 1991 'Atiqot 20;1-26 with comment by the editor)

Shimoni C. and Shamir O. 1994. Gesher Haziv-Textile Remains on Coins. 'Atiqot 25:97

Taha, A. 1982. Men's Costume in Palmyra. Les Annales Archeologiques Arabes Syriennes 32:117-132

Winter, T. The Glass Vessels. 1996. In: Avni G. and Greenhut Z. (eds.) The Akeldama Tombs, Jerusalem

Vogelsang-Eastwood G.M. 1988a. The Development and Spread of Compound Weave Textiles with Particular Reference to Weft-Faced Compound Weave Textiles in Wool from Egypt. Ph.D. Dissertation, University of Manchester. Manchester

Yadin, Y. 1963. Finds from the Bar Kokhba Period in the Cave of Letters. Jerusalem

Zissu B, Gibson, S. and Tavor, J. 2000. Jerusalem, Ben Hinom Valley. Hadashot Arkheologiyot 111: 70-72* 